\title{
Analysis of the changes with respect to the authorized donees in the Fiscal Code of the Federation of 2020, legal and accounting aspects
}

\section{Análisis de los cambios con respecto a las donatarias autorizadas en el Código Fiscal de la Federación de 2020, aspectos jurídicos y contables}

\author{
RUIZ-MEDRANO, Salvador Francisco $\dagger^{*} \&$ GALVÁN-ZAVALA, Karina \\ Universidad de Guanajuato, Division of Administrative Economic Science, Guanajuato Campus, Department of Business \\ Management and Management, Department of Organizational Studies, Mexico.
}

ID $1^{\text {st }}$ Author: Salvador Francisco, Ruiz-Medrano / ORC ID: 0000-0002-8120-2274, CVU CONACYT ID: 253989

ID 1 ${ }^{\text {st }}$ Co-author: Karina, Galván-Zavala / ORC ID: 0000-0001-5759-8814, CVU CONACYT ID: 273545

DOI: $10.35429 / J A F .2021 .22 .8 .9 .15$

Received January 15, 2021; Accepted June 30, 2021

\begin{abstract}
Mexico is the fifth country that collects the least in Latin America as a proportion of gross domestic product (GDP) and also the one with the lowest income from the value added tax, has highlighted the Organization for Economic Cooperation and Development (OECD) in the year 2020, (OCDE, 2020) derived from this, the Federal Executive proposed a series of reforms that allow increasing collection, among which the most notable is the Decree that reforms, adds and repeals various provisions of the Tax Law on the Income, the Law of Value Added Tax and the Fiscal Code of the Federation which has a direct effect on the so-called Authorized Grantees, this based on the fact that cases have been detected in which the income of the Authorized Grantees is not found. related to the activity authorized by the Law and carry out simulated operations. The objective of this work is to analyze the effects that this reform will have and try to foresee its immediate success.
\end{abstract}

Income Tax Act, Reforms 2020, Authorized Donors

\begin{abstract}
Resumen
México es el quinto país que menos recauda en América Latina como proporción del producto interno bruto (PIB) y también el que tiene los ingresos más bajos del impuesto al valor agregado, destacó la Organización para la Cooperación y el Desarrollo Económicos (OCDE) en el año 2020, (OCDE, 2020) derivada de esto, el Ejecutivo Federal propuso una serie de reformas que permitan incrementar la recaudación, entre las que destaca el Decreto que reforma, suma y excepciones diversas disposiciones de la Ley Tributaria sobre la Renta, la Ley del Impuesto al Valor Agregado y el Código Fiscal de la Federación que tiene un efecto directo en los llamados Concesionarios autorizados, esto basado en el hecho de que se han detectado casos en los que no se encuentran los ingresos de los concesionarios autorizados. relacionada con la actividad autorizada por la Ley y llevar a cabo operaciones simuladas. El objetivo de este trabajo es analizar los efectos que tendrá esta reforma y tratar de prever su éxito inmediato.
\end{abstract}

Ley del Impuesto sobre la Renta, Reformas 2020, Donatarias autorizadas

Citation: RUIZ-MEDRANO, Salvador Francisco \& GALVÁN-ZAVALA, Karina. Analysis of the changes with respect to the authorized donees in the Fiscal Code of the Federation of 2020, legal and accounting aspects. Journal of Administration and Finance. 2021. 8-22:9-15.

\footnotetext{
* Correspondence to Author (Email: salvador.rm@ugto.mx)

$\dagger$ Researcher contributing first author.
} 


\section{Introduction}

In the explanatory memorandum of the draft decree initiative that reforms, adds and repeals various provisions of the Income Tax Law. The federal Executive indicates that, in the sense of not creating new taxes, as well as fighting corruption and impunity head-on, the initiative includes proposals that move along the following axes: administrative simplification and legal certainty, modernization, tax management, collection efficiency, combat corruption and impunity, tax evasion and avoidance.

The axis of tax evasion and avoidance corresponds to the following approaches: adjustments are proposed in order to strengthen the monitoring of the merger and division of companies, transmission of tax losses, tax refunds, tax receipts that presumably cover simulated operations, authorized donees, tax reports, conclusive agreements, transfer prices and cancellation of the federal taxpayer registry, as these are cases in which the tax authority has detected practices that result in tax evasion or avoidance.

The 2020 tax reform brings with it significant changes in terms of preventing and combating corruption in Mexico, it is important to review the positive effects of the tax reform in terms of authorized donees, one of the main successes is to combat tax evasion and avoidance of organizations that divert resources and are operating through the figure of civil association, and that also has the distinction of being an authorized donee.

This study is approached from the legal and accounting approach that reviews the foundation of the reform in the Income Tax Law and its implications in the operation of authorized donees.

It is noted that most of the income that the authorized donees obtain is not related to the purpose for which they obtained their authorization. According to the 2019 authorized donee report issued by the Tax Administration Service SAT, the income of legal entities authorized to receive deductible donations for income tax purposes is classified according to the following:

\begin{tabular}{|l|c|r|}
\hline \multicolumn{1}{|c|}{ Concept } & \multicolumn{1}{c|}{ Amount: } & Percentage \\
\hline Donations & $\$ 47,659,423,027.00$ & $24 \%$ \\
\hline $\begin{array}{l}\text { Income related } \\
\text { to the corporate } \\
\text { purpose }\end{array}$ & $\$ 20,276,273,378.00$ & $10 \%$ \\
\hline $\begin{array}{l}\text { Income not } \\
\text { related to the } \\
\text { corporate } \\
\text { purpose }\end{array}$ & $\$ 132,323,707,585.00$ & $66 \%$ \\
\hline Total & $\$ 200,259,403,990.00$ & $100 \%$ \\
\hline
\end{tabular}

Table 1 Participation of the different types of income of the authorized donees for 2019

Source: Own elaboration from SAT data

\section{A first general analysis}

Although the reform had been planned for a long time, it was not until September of last year that the President delivered the initiative for a Decree that amended, added and repealed various provisions of the Income Tax Law, of the Law on Value Added Tax and the Fiscal Code of the Federation which has a direct effect on the socalled Authorized Grantees, which are all nonprofit associations that pursue philanthropic objectives. The Income Tax Law describes them as all those associations that do not seek to generate a profit, therefore they enjoy fiscal benefits, it is precisely these benefits that the reform affects, since the tax authority has detected that most of the income obtained by authorized donees is not related to the purpose for which they obtained their authorization; Therefore, an eighth paragraph was added to article 80 of the Income Tax Law, so that if the authorized donees obtain most of their income (more than 50\%) from activities not related to their corporate purpose, lose their authorization (Arzate López, 2021), in this way the paragraph in comment is as follows (Chamber of Deputies of the $\mathrm{H}$. Congress of the Union, 2021):

"In the event that the people referred to in the previous paragraph obtain income from activities other than the purposes for Those who were authorized to receive donations in a percentage greater than $50 \%$ of the total income for the fiscal year will lose the corresponding authorization, which will be determined by resolution issued and notified by the fiscal authority. If within the twelve months following the loss of authorization to receive deductible donations from income tax, said authorization is not obtained again, they must allocate all their assets to another authorized donee to receive deductible donations." 
Another change in relation to the socalled simulated operations, where the reform initiative indicated that at least 2,000 authorized donees have carried out operations with companies that invoice simulated operations, as mentioned in the statement of reasons for the reform (Arzate López, 2021 ) that is, they obtained benefits of a tax nature that are clearly illegal that affect the economic capacity of the State and the benefit of the people.

\section{The income tax law}

The core of all this reform is found in the Income Tax Law (Chamber of Deputies of the $\mathrm{H}$. Congress of the Union, 2021), specifically in Title III, Of the Regime of Legal Persons with Non-Profit Purposes, specifically in its article 79, which by letter explains:

"The following legal persons are not taxpayers of income tax:... . XI. Non-profit civil societies or associations authorized to receive deductible donations under the terms of this Law, dedicated to scientific or technological research that are registered in the National Registry of Scientific and Technological Institutions ... XVII. Associations or civil societies, organized non-profit and authorized to receive deductible donations in the terms of this Law, that grant scholarships, referred to in article 83 of this Law... XIX. The civil societies or associations, organized non-profit and authorized to receive deductible donations in the terms of this Law, that are constituted and function exclusively for the carrying out of research activities or preservation of the wild, terrestrial or wild flora or fauna. within the defined geographic areas indicated by the Tax Administration Service through general rules, as well as those that are constituted and function exclusively to promote the prevention and control of water, air and pollution among the population. of the soil, the protection of the environment and the preservation and restoration of the ecological balance... XX. Non-profit associations and civil societies authorized to receive deductible donations under the terms of this Law, which prove that they are exclusively dedicated to the reproduction of species in protection and danger of extinction and to the conservation of their habitat, provided that in addition To comply with the general rules issued by the Tax Administration Service, a prior opinion is obtained from the Ministry of the Environment and Natural Resources.
The legal entities referred to in sections V, VI, VII, IX, X, XI, XIII, XVI, XVII, XVIII, XIX, $\mathrm{XX}, \mathrm{XXIV}$ and XXV of this article, as well as the legal entities and trusts authorized to receive Tax-deductible donations, and the investment funds referred to in this Title, will consider the remnant distributable, even when they have not delivered it in cash or goods to their members or partners, the amount of the omissions of income or the purchases not made. and improperly registered; the expenditures they make and are not deductible under the terms of Title IV of this Law; The loans that they make to their partners or members, or to the spouses, ascendants or descendants in a straight line of said members or members, except in the case of loans to members or members of the savings and loan cooperative societies referred to in the fraction XIII of this article. In the case of loans that in the terms of this paragraph are considered distributable remnant, their amount will be reduced from the distributable remnants that the legal entity distributes to its partners or members.

In the case in which a distributable remnant is determined in the terms of the preceding paragraph, the legal entity in question will pay as a tax the tax that results from applying on said distributable remnant, the maximum rate to be applied on the surplus of the lower limit that establishes the rate contained in article 152 of this Law, in which case it will be considered as a final tax, having to make the corresponding integer no later than the month of February of the year following the one in which any of the assumptions occurs referred to in said paragraph. " It should be clarified that the reform to sections XI, XVII, XIX and XX of article 79 in the Official Gazette of the Federation on December 8, 2020 will enter into force on July 1, 2021, and it is for this reason that they are the only ones that are mentioned here. As can be seen from the previous reading, the most significant change is related to the so-called distributable remnant, which will cause taxes in accordance with the rate contained in article 152 of the Income Tax Law, when they result, in general terms, of what could be called "simulated operations".

Where the loans they make to their partners or members, or to the spouses, ascendants or descendants in a straight line of said partners or members are mentioned ... the corresponding integer must be made no later than the month of February of the following year ... 
Likewise, article 80 states that in the event that legal entities whose activity is for nonprofit purposes dispose of goods other than their fixed assets or provide services to persons other than their members or partners, they must determine the tax that corresponds to the profit from the income derived from the aforementioned activities, provided that said income exceeds $5 \%$ of the total income of the legal entity in the year in question, and likewise, the legal entities and trusts authorized to receive tax-deductible donations may obtain income from activities other than the purposes for which they were authorized to receive said donations, provided that they do not exceed $10 \%$ of their total income in the year in question, however, when these legal entities obtain income from different activities for the purposes for which they were authorized to receive donations in a percentage greater than $50 \%$ of the total i Income for the fiscal year will lose the corresponding authorization. In this case, the modification made by the legislature refers to the abuse that the authorized donees could incur when obtaining a 50\% higher income through activities other than those that are authorized, which would validate the hypothesis that its true income and therefore profit, derives from other activities and not only from those for which it was authorized.

Continuing with the updating of the Law, its article 82 provides that legal entities whose activity is for non-profit purposes, must comply with the following to be considered as authorized institutions to receive deductible donations in the terms of this Law: "I... II ... III... IV. That they allocate their assets exclusively for the purposes of their corporate purpose, for which they have been authorized to receive deductible donations from income tax, not being able to grant benefits on the remaining distributable to any individual or to their members, individuals or companies, except in the case, in the latter case, of any of the legal entities or trusts authorized to receive taxdeductible donations or the remuneration of services actually received.

\begin{abstract}
"That as already mentioned above, it is in line with avoiding the simulation of operations, and that it is also complemented with the fraction V which indicates: "V. That, at the time of their liquidation or change of residence for tax purposes, they allocate all of their assets to entities authorized to receive deductible donations. In cases of revocation of the authorization or when its validity has ended and it has not been obtained again or renewed, within the twelve months following the date on which such events occur, all of its assets must be allocated to other entities authorized to receive donations deductible from income tax who must issue the corresponding tax receipt for donation, which will not be deductible for income tax purposes. The legal entities referred to in the preceding paragraph shall pay tax under the terms and conditions established in Title II of this Law. The resources that must be allocated to other authorized donees must be transmitted within a period of 6 months from the end of the the term to obtain the authorization again when it was revoked or the expiration of the authorization. The provisions of the preceding paragraph will also be applicable in the event that an authorized donee is approved her request to cancel her authorization, who must allocate all her assets to another authorized donee to receive donations deductible from income tax and the latter must issue the corresponding tax receipt for donation, which will not be deductible for income tax purposes."
\end{abstract}

These reforms regarding the so-called "destination of the patrimony", have found diverse critical voices since it directly threatens the private property and the assets of the associates of the association, as well as the fact of revoking the authorization will immediately render inoperative to the association, since de facto it will lose assets and infrastructure, and therefore, its operation will be affected, making it impossible to offer the services it was granting, prior to the revocation of registration as Authorized Grantee (Arzate López, 2021), that is, it is made a de facto confiscation of the patrimony without any economic compensation so that it is donated to another authorized donee. The measure is clearly questionable and will most likely be subject to controversy in a guarantee trial, since, although it is true that the non-profit purpose of an association is merely philanthropic, this does not lead to turning the associations into martyrs. that they have to lose their patrimony in order to keep it for altruistic purposes.

RUIZ-MEDRANO, Salvador Francisco \& GALVÁN-ZAVALA, Karina. Analysis of the changes with respect to the authorized donees in the Fiscal Code of the Federation of 2020, legal and accounting aspects. Journal of Administration and Finance. 2021 
In short, the free disposition of property should be a right that is little questioned by the authorities and should not be directed to an altruistic purpose without taking into account the wishes of the owners. In the exercise practiced by the Chamber of Deputies called "Open Parliament", the arguments of the non-profit associations prevailed that exposed, in some cases dramatically, that the reforms, although they seek to deactivate abusive practices, would also damage the financing and operation of the few associations that are dedicated to the care of goods, people, animals, cultural and artistic heritage in our country (Arzate López, 2021).

Continuing with the new changes to the Law, Article 82-Quáter, indicates that civil organizations and trusts whose authorization to receive deductible donations for income tax purposes has been revoked for the aforementioned causes, will not be able to obtain the authorization to receive deductible donations, until they correct the reason for which they were revoked or, if applicable, pay the corresponding income tax.

In this way, a premise that has been constant during the current government is fulfilled, which is the reparation of damage, from a pecuniary point of view, in order to continue operating or in more serious cases, obtain benefits of early release or reduction of sentence.

In this same article added by the reform, a procedure is provided to carry out the revocation which will be initiated by the Tax Administration Service in accordance with the following:

I. It will issue an official letter through which it informs the authorized donee of the grounds for revocation in order for her to manifest before the tax authority what is appropriate to her right, where all kinds of evidence will be admitted, except for testimonial and confessional evidence. charge of the authorities.

II. Once the term has expired, the tax authority will issue the corresponding resolution within a term that will not exceed three months, counted from the day following that on which the referred term expired.
III. The resolution indicated in the preceding section will be notified in accordance with the applicable tax provisions.

\section{Financing strategies of civil society organizations}

One of the most recurrent problems for civil associations is related to the financing of their operations, (Muñoz Hernández, 2012) In Muñoz Hernández, it is pointed out that one of the most important problems of CSO networks to obtain financing is that of give trust and credibility to your donors. Instruments have recently been designed from the public and private sectors to increase the trust and credibility of CSOs, to guarantee CSO donors that their resources will be well applied. These instruments are from the public sector the certification for CSOs that they are authorized donees endorsed by the Tax Administration System (SAT) of the Ministry of Finance.

For his part, Jorge Villalobos, leader of the Mexican Center for Philanthropy (CEMEFI), said that in Mexico there are 9 thousand authorized grantees whose donations rose from 34 billion pesos six years ago to 47 billion pesos this year.

\section{Effects on the accounting income of civil associations}

The volume of authorized donees who receive income not related to their corporate purpose is incremental, the referred income from activities other than the corporate purpose represent $66 \%$ of total income, which represents a concentration of income from lucrative activities.

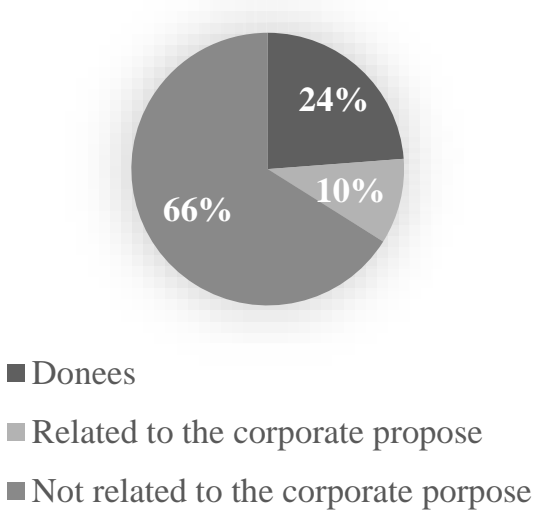

Graphic 1 Percentage of income from authorized donees 2019

Source: Own elaboration from SAT data 
The last paragraph of article 80 of the Income Tax Law states that they can only obtain income from activities other than the purposes for which they were authorized to receive said donations, provided that they do not exceed $10 \%$ of their total income in the exercise in question.

The reform proposes that in the event that authorized donees obtain most of their income (more than 50\%) from activities not related to their corporate purpose, they lose their authorization, in order to prevent these entities from carrying out activities aimed at obtaining a profit.

The following Table shows the variable income obtained by civil associations that have the distinctive of authorized donees, with the tax reform, those authorized donees who obtain more than $50 \%$ of their income from income not related to their corporate purpose will lose the registry of donee Authorized Tax Administration System.

\begin{tabular}{|l|l|l|l|l|}
\hline \multicolumn{1}{|c|}{ Variable } & \multicolumn{2}{c|}{$\mathbf{2 0 2 1}$} & \multicolumn{1}{c|}{ Support } & Incidence \\
\hline $\begin{array}{l}\text { Percentage } \\
\text { of income } \\
\text { not related } \\
\text { to the } \\
\text { corporate } \\
\text { purpose to } \\
\text { continue } \\
\text { with the } \\
\text { registration } \\
\text { of } \\
\text { authorized } \\
\text { done. }\end{array}$ & & $<50 \%$ & $\begin{array}{l}\text { Article 80 } \\
\text { LISR } \\
\text { eighth } \\
\text { paragraph }\end{array}$ & $\begin{array}{l}\text { Reduce the } \\
\text { tendency } \\
\text { and } \\
\text { propensity } \\
\text { to profit on } \\
\text { the part of } \\
\text { authorized } \\
\text { donees. }\end{array}$ \\
\end{tabular}

Table 2 Main changes for authorized donees in the area of income tax after the 2021 tax reform in terms of income Source: Own elaboration based on the draft explanatory memorandum for the 2021 tax reform

\section{Effects on accountants on the deductibility of donations}

According to the Mexican Center for Philanthropy (CEMEFI), the volume of donations received by civil associations with an authorized donee registration issued by the Tax Administration System (SAT) has been incremental in recent years, which shows that the Mexican taxpayers have a high propensity to make donations and consequently deduct these expenses from paying their taxes.

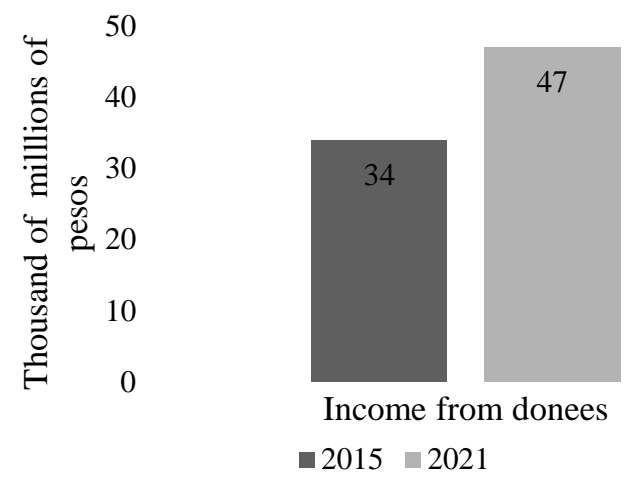

Graphic 2 Authorized grantees of the Mexican Center for Philanthropy

Source of Consultation: Own elaboration from the Mexican Center for Philanthropy

The nomination of authorized donee is also considered as a very important fundraising tool for CSOs since for each donation they receive they can deliver a tax deductible receipt, $7 \%$ of the ISR. With this nomination the income they receive as a donation is tax free, they only pay taxes on salaries. (Muñoz Hernández, 2012)

Given this, the increase in the collection of donations from the income from donations should be influenced, it is extremely important for civil associations to retain the distinctive of authorized donee so and in order to continue issuing tax receipts for the deductibility of donors.

\section{Conclusions and relevant aspects of the ISR reform}

The 2020 tax reform brings with it significant changes in terms of preventing and combating corruption in Mexico, it is important to review the positive effects of the tax reform in terms of authorized donees, one of the main successes is to combat tax evasion and avoidance of organizations that divert resources and are operating through the Figure of civil association, and that also has the distinction of being an authorized donee. 
Article 80 of the Income Tax Law states that in the event that legal entities whose activity is for non-profit purposes dispose of goods other than their fixed assets or provide services to persons other than their members or partners, they must determine the tax. that corresponds to the profit from the income derived from the aforementioned activities, provided that said income exceeds $5 \%$ of the total income of the legal entity in the year in question, and likewise, the legal entities and trusts authorized to receive donations Tax deductible may obtain income from activities other than the purposes for which they were authorized to receive said donations, provided that they do not exceed $10 \%$ of their total income in the fiscal year in question, however, when these legal entities obtain income for activities other than the purposes for which they were authorized to receive donations in a percentage greater than $50 \%$ of the total income for the fiscal year, they will lose the corresponding authorization. In this case, the modification made by the legislature refers to the abuse that the authorized donees could incur when obtaining a $50 \%$ higher income through activities other than those that are authorized, which would validate the hypothesis that its true income and therefore profit, derives from other activities and not only from those for which it was authorized.

The reform provides a procedure to carry out the revocation which will be initiated by the Tax Administration Service in accordance with the following:

I. It will issue an official letter through which it informs the authorized donee of the grounds for revocation in order for her to manifest before the tax authority what is appropriate to her right, where all kinds of evidence will be admitted, except for testimonial and confessional evidence. charge of the authorities.

II. Once the term has expired, the tax authority will issue the corresponding resolution within a term that will not exceed three months, counted from the day following that on which the referred term expired.

III. The resolution indicated in the preceding section will be notified in accordance with the applicable tax provisions.
The volume of authorized donees that receive income not related to their corporate purpose is incremental, the referred income from activities other than the corporate purpose represent $66 \%$ of total income, which represents a concentration of income from lucrative activities.

Confronting tax evasion and avoidance is one of the central axes of the tax reform, which is considered positive, however, the financing challenges for the operation of civil associations will continue to be an important challenge to continue with the march and work for part of these organisms.

\section{References}

Arzate López, J. A. (15 de enero de 2021). Estrategia Aduanera, La revista mexicana de Comercio Exterior. Recuperado el 10 de marzo de 2021, de Ecos de la reforma fiscal 2021. Donatarias autorizadas. Las letras chiquitas de la reforma:

https://www.estrategiaaduanera.mx/ecos-de-lareforma-fiscal-2021-donatarias-autorizadas-lasletras-chiquitas-de-la-reforma/

Cámara de Diputados del H. Congreso de la Unión. (9 de marzo de 2021). Cámara de Diputados del H. Congreso de la Unión LXIV Legislatura. Recovered on March 19, 2021, from Leyes Federales de México: http://www.diputados.gob.mx/LeyesBiblio/pdf/ 84_070519.pdf

Muñoz Hernández, R. (2012). Las redes organizaciones de la sociedad civil en México y sus estrategias de financiamiento. Administración y Organizaciones , 15, 11-37.

OCDE. (7 de mayo de 2020). OCDE. Recuperado el 25 de febrero de 2021, de América Latina y el Caribe: el aumento de los ingresos tributarios se ve amenazado en medio del deterioro de las perspectivas regionales: http://www.oecd.org/tax/tax-policy/americalatina-y-el-caribe-el-aumento-de-los-ingresostributarios-se-veamenazado-en-medio-deldeterioro-de-las-perspectivas-regionales.htm 